During the period the comet moves in a north-easterly direction, its path lying about midway between the belt of Orion and Sirius. From March 8 to Io it will be passing near the fourth mag. double star $\boldsymbol{\beta}$ (II) Monocerotis.

Comet Chase, r898 VIII.-E. F. Coddington gives, also in Ast. Nach., No. 3544, a revised ephemeris and table of elements for this comet, which he has computed from observations made by him at Mount Hamilton on November 23, December 7 and December 16,1898 .

$$
\text { Elements. }
$$

$\mathrm{T}=$ I898, Sept. 20.15344 G.M.T.

$$
\begin{aligned}
& \left.\omega=\begin{array}{lll}
4 & 37 & 59 \\
\hline & 9
\end{array}\right) \\
& \left.\Omega=955^{\mathrm{I}} 35^{\circ} 9\right\} \text { I } 899^{\circ} \mathrm{O} \\
& i=22 \text { 30 20.3 }
\end{aligned}
$$

$\log q=0.358892$.

$$
\text { Ephemeris for Greenwich Midnight. }
$$

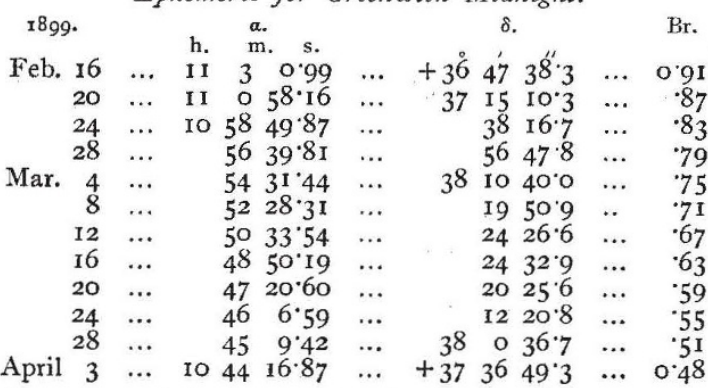

Comparison of the elements leads to the orbit being considered almost parabolic, and hence there is no probability of its bein identical with that of Comet I867 I., as has been suggested. The comet is now rapidly receding from the sun and decreasing in brightness. It is moving slowly westwards between the pairs of stars $\gamma, \xi$ and $\lambda \mu$ Ursæ Majoris.

Variation of Spectrum of Orion Nebula.-Much has been recently said as to whether the spectrum of this nebula is different in different regions. There seems to be no doubt that in different parts certain lines are intensified or reduced relatively to others, but observers are not yet agreed as to the reality of the difference, many ascribing it to physiological causes. Prof. J. E. Keeler, with the Lick 36 -inch refractor, has examined it with reference to this matter (Ast. Nach., No. 354I). Near the star Bond 734 the strongest line was $\mathrm{H}_{\beta}(\mathrm{F})$. With the slit on the Huyghenion region, near the trapezium, the strongest line was the chief nebula line ( $\lambda$ 5007), while $\mathrm{H}_{\beta}$ and the second nebula line ( $\lambda$ 4959) were about equally bright, but much less intense than the chief line. Still keeping the slit in this region, the vertical aperture of the spectroscope was diminished without altering the resolving power. When the brightness was sufficiently reduced, $\mathrm{H}_{\beta}$ and the line $\lambda 4959$ disappeared, leaving $\lambda 5007$ alone visible. Thus in one part of the nebula $\mathrm{H}_{\beta}$ alone was visible, in another $\lambda$ 5007. This is inexplicable on physiological grounds, and would seem to point to real differences in the composition of the nebula.

Latitude Determination.- - In the determination of latitude by Tallcott's method, the apparent mean declination of a pair of stars has to be deduced from observations of the star corrected by constant factors dependent on the position of the stars. To facilitate these reductions H. Kimura, of the Tokyo Observatory, gives formulæ and tables for constructing mean star factors (Ast. Nach., Bd. I48, No. 354I). There are also four special tables of these constants given for the particular latitude $\phi=39^{\circ} 8^{\prime} 10^{\prime \prime}$, which is that chosen for a number of stations for the coming international work of determining latitude variation.

Lynn's "Remarkable Comets."-A new edition-the seventh-of this handy little volume has been published by Mr. Edward Stanford. The periodic comets which may be expected to return this year are stated by Mr. Lynn as follows : Spring-The comet of 1866 , connected with November meteors (period, $33 \frac{1}{3}$ years). Summer-Tuttle's comet (period, I $33^{\frac{3}{4}}$ years), Tempel's second periodical comet (period, $5 \frac{1}{4}$ years), and Holme's comet (period, nearly 7 years). WinterFinlay's comet (period, 61 years).

NO. I 529, voL. 59]

\section{THE THEORY OF THE STASSFURT SALT} DEPOSITS.

"THE formation of the salt deposits at Stassfurt, Wieliczka, and other places, so far as they are of an oceanic origin, can. not receive a detailed explanation until the conditions of equilibrium affecting the salts dissolved in sea-water have been subjected to a systematic investigation.

"First of all, it must be ascertained what grouping the radicals assume in the solid state; that is to say, what solid substances separate out as sea-water is evaporated. Further experiments will then show us how the composition of sea-water is affected by the presence of the various solids, and whether, and to what degree, changes take place-loss of water of crystallisation, formation of double salts, and kindred phenomena-as the composition of the solution alters, until finally the water is wholly evaporated, and a stable system of solids is left behind."

The comprehensive programme of work thus indicated by Dr. Meyerhoffer in 1895 has been seriously entered upon, and the first instalment of results appears in a recent number of the Zeitschrift für Physikalische Chemie, vol. xxvii. p. 75. ${ }^{1}$

The investigation promises to be of great interest and irsportance, viewed both from the theoretical and practical stand points. The problem of determining the conditions under which a series of salts have been deposited during the concentration of a dilute solution, is very much more complicated than might at first sight appear, and can only be solved by the application of methods and principles that are of recent discovery. The researches that render the investigation possible have been mainly conducted during the past few years in the laboratory of Prof. van't Hoff; and those who are acquainted with the admirable "Études sur les equilibres chimiques" (translated into English by Dr. Ewan), and with the later publications of van ' $t$ Hoff, will know how ably he has developed the theory of equilibrium as applied to the existence of hydrates and of double salts.

The plan of work, with respect to the Stassfurt deposits, is as follows. The chief dissolved substances in sea-water consist of salts formed from $\mathrm{Cl}, \mathrm{SO}_{4}, \mathrm{Na}, \mathrm{K}$ and $\mathrm{Mg}$; the first problem is, therefore, the complete investigation of the salts and solutions producible from these radicals. Even within these limits the investigation is too complicated ; so that, first of all, systems formed by water with the chlorides and sulphates of $\mathrm{K}$ and $\mathrm{Mg}$ are dealt with. Then the consideration is extended to such systems with the addition of rock salt, and the first part of the investigation is concluded.

In the second part the less soluble and less abundant components of the deposits will be considered. Calcium, in the first instance, will receive attention; and then the compounds of boron, bromine, and iron.

The groups of substances to be dealt with are as follows :-

(I) Group formed from the sulphates and chlorides of $\mathrm{K}$ and $\mathrm{Mg}$.

$\mathrm{MgCl}_{2}$ and its hydrates.

Sylvine, $\mathrm{KCl}$ and $\mathrm{K}_{2} \mathrm{SO}_{4}$.

$\mathrm{MgSO}_{4}$ and its hydrates ; Carnallite, $\mathrm{MgCl}_{2}, \mathrm{KCl} .6 \mathrm{H}_{2} \mathrm{O}$.

Schönite, $\mathrm{MgSO}_{4}, \mathrm{~K}_{2} \mathrm{SO}_{4} \cdot 6 \mathrm{H}_{2} \mathrm{O}$, and potassium astrakanite $\mathrm{MgSO}_{4}, \mathrm{~K}_{2} \mathrm{SO}_{4} \cdot 4 \mathrm{H}_{2} \mathrm{O}$.

Kainite, $\mathrm{MgSO}_{4}$, KCl. ${ }_{3} \mathrm{H}_{2} \mathrm{O}$, and Langbeinite $2 \mathrm{MgSO}_{4}$ $\mathrm{K}_{2} \mathrm{SO}_{4}$.

(2) With the addition of $\mathrm{NaCl}$.

$\mathrm{NaCl}$ and $\mathrm{Na}_{2} \mathrm{SO}_{4}$ and their hydrates.

Astrakanite (Blödite), $\mathrm{MgSO}_{4}, \mathrm{Na}_{2} \mathrm{SO}_{4}, 4 \mathrm{H}_{2} \mathrm{O}$.

Glaserite (Penny's salt), $\mathrm{K}_{3} \mathrm{Na}\left(\mathrm{SO}_{4}\right)_{2}$.

(3) With the addition of Calcium.

$\mathrm{CaCl}_{2}$ and its hydrates.

Tachydrite, $\mathrm{CaCl}_{2} \cdot 2 \mathrm{MgCl}_{2} \cdot 12 \mathrm{H}_{2} \mathrm{O}$.

Gypsum, $\mathrm{CaSO}_{4} \cdot 2 \mathrm{H}_{2} \mathrm{O}$, Anyhdrite $\mathrm{CaSO}_{4}$, and their double salts, such as Krugite, Glauberite, Polyhalite, Syngenite, Mamannite, \&c.

(4) With the addition of Boron, Bromine and Iron.

Boracite, Stassfurtite.

Magnesium bromide.

Potassium ferrochloride, \&c.

The first instalment of the research, now published, deals exclusively with the hydrates of magnesium chloride. The

1 Über Anwendungen der Gleichgewichtslehre auf die Bildung oceanischer Salzablagerungen, mit besonderer Berücksichtigung des Stassfurter Salzlagers. Von J. H. van 't Hoff und W. Meyerhoffer. 
limits of existence of the following hydrates within $-33^{\circ} \cdot 6 \mathrm{C}$. and $186^{\circ} \mathrm{C}$. (the temperature at which water begins to decom. pose magnesium chloride) have been investigated :-

$\mathrm{MgCl}_{2} \cdot \mathrm{I}_{2} \mathrm{H}_{2} \mathrm{O}, \mathrm{MgCl}_{2} \cdot 8 a \mathrm{H}_{2} \mathrm{O}, \mathrm{MgCl}_{2} .8 \beta \mathrm{H}_{2} \mathrm{O}, \mathrm{MgCl}_{2} 6 \mathrm{H}_{2} \mathrm{O}$, $\mathrm{MgCl}_{2} \cdot 4 \mathrm{H}_{2} \mathrm{O}, \mathrm{MgCl}_{2} \cdot 2 \mathrm{H}_{2} \mathrm{O}$.

It is impossible within the limits of this notice to discuss the details of the investigation, but the brief indication here given of the nature and scope of the inquiry may serve to direct attention to a research which is obviously of wide interest.

\section{THE NATURAL HISTORY OF CORDIERITE AND ITS ASSOCIATES. ${ }^{1}$}

THE last quarter of the present century has witnessed an extraordinary outburst of petro'ogical activity, due, in a large measure, to the application of precise mineralogical methods to the study of the constituents of rocks. The petrologist, and through him the geologist, owes, therefore, an enormous debt of gratitude to the mineralogist ; at the same time, the benefits have not been wholly one-sided. Mineralogy is becoming something more than a mere catalogue of the crystallographic, chemical and physical characters of museum. specimens, and this is largely due to the influence of petrology. It may end in breaking down the artificial systems of classification which are in vogue, and introducing others more in accordance with genetic principles.

A good illustration of the advantage of studying minerals from the natural history point of view may be obtained by considering some facts relating to the modes of occurrence and origin of corundum, spinelle, sillimanite and cordierite-four minerals which are so frequently found together that they have been called the "faithful companions." Corundum is crystallised alumina $\left(\mathrm{Al}_{2} \mathrm{O}_{3}\right)$, true spinelle is an aluminate of magnesia $\left(\mathrm{MgO} . \mathrm{Al}_{2} \mathrm{O}_{3}\right)$, sillimanite is the silicate of alumina $\left(\mathrm{Al}_{2} \mathrm{O}_{3} \cdot \mathrm{SiO}_{2}\right)$, and cordierite is a silicate of alumina and magnesia $\left(2 \mathrm{MgO} \cdot 2 \mathrm{Al}_{2} \mathrm{O}_{3} \cdot 5 \mathrm{SiO}_{2}\right)$. The mutual replacing properties of ferrous oxide and magnesia, and of ferric oxide and alumina complicate the composition of the spinelles and cordierite. All the minerals contain alumina, and it is this fact which determines their paragenesis. They occur, usually in combinations of two or more, under the most diverse geological conditions :-

(I) As the constituents of foliated crystalline rocks of more or less doubtful origin.

(2) As the products of contact-metamorphism round plutonic masses.

(3) As the constituents of inclusions in plutonic rocks, dykes, lavas and agglomerates.

(4) As the direct products of the crystallisation of igneous magmas.

(5) As the direct products of the crystallisation of artificial silicate-magmas.

Cordierite-gneisses are found in many parts of the world in association with biotite-gneisses and other foliated crystalline rocks. Various views have been expressed as to their origin. Some petrologists are content to refer them to the Archæan system ; others regard them as due to the contact or thermo. dynamic metamorphism of ordinary argillaceous sediments and others as rocks of mixed origin, containing both igneous and sedimentary material. The last view, as applied to certain members of the group but not to all, derives support from the fact that where cordierite-rocks occur as contact products, they always belong to the inner zone, and sometimes give distinct evidence of the intimate intermixture of igneous and sedimentary material.

Cordierite-rocks, often containing sillimanite and a green spinelle, have been recognised, during the progress of the Geological Survey, at many points in the Southern Highlands of Scotland, in the counties of Aberdeen, Banff, Forfar and Argyle, and quite recently corundum has been detected in some of these ; so that the list of the "faithful companions" is now complete so far as Scotland is concerned. It is doubtful at present whether all the Scottish cordierite-rocks are of the same age and mode of origin. Some are contact-rocks, but others may, for the present at least, be more safely classed with the older crystalline-schists. All are undoubtedly the result of the metamorphism of highly aluminous rocks.

1 Abstract of the presidential address delivered to the Geologists' Association, by J. J. H. Teall, F.R.S., on February 3.
A very interesting case of the occurrence of all four minerals in rocks due to contact-action has been described by Salomon. It occurs in the southern part of the Eastern Alps round the great mass of tonalite, of which Monte Adamello forms the culminating point.

Inclusions, derived either from a contact-zone or from the crystalline-schist formation, containing two or more of the minerals in question, have been observed in igneous rocks occurring under the most diverse conditions in many parts of the world. They have been found, for example, in the tonalite of Monte Aviolo; in the kersantite-dyke of Michaelstein in the Hartz; in the andesitic lavas of the Eifel, the Siebengebirge and the south-east of Spain; and, finally, amongst the ejected blocks of the Laacher See and Asama Yama in Japan. There is evidence, moreover, that in most of these cases the minerals, or some of them, occur not only as constituents of the inclusions, but also as the direct products of crystallisation from the igneous magmas. Thus, in the mica-andesite of Hoyazo (Cabo di Gata) cordierite occurs in two forms: (I) as irregularly bounded grains up to the size of a hazel-nut, and (2) as sharply defined idiomorphic crystals in a glassy base. The former are inclusions; the latter are crystals which have separated from the magma. Rock-fragments, consisting very largely of a cordierite-gneiss from which the isolated grains of cordierite have been derived, are also very common in this andesite. Osann, who has described this very interesting case, points out that the abun. dance of indigenous cordierite, coupled with the presence of numerous inclusions of cordierite and cordierite-gneiss, points to the conclusion that portions of the foreign rock have been dissolved, and that a magma of exceptional composition has thus been formed, out of which cordierite has crystallised. Many other cases are known in which the solution of foreign aluminous material has so modified a magma that members of the group under consideration have crystallised out of it. Moreover, it is not necessary that the minerals should be present in the foreign material. It is sufficient that the necessary chemical constituents should be present. Thus a basalt from Köllnitz in Carinthia has involved fragments of an argillaceous rock, and partially dissolved them. The normal basalt is holocrystalline, but in the neighbourhood of the inclusions it becomes glassy, and crystals of spinelle and cordierite, which are absent, both from the basalt and the inclusion, occur. The partial solution of the fragments evidently modified the composition of the basalt, so that it cooled as a glass after cordierite and spinelle had separated out. It is interesting to note, in passing, that the addition of alumina to the hasaltic magna has tended to prevent crystallisation. This effect of alumina is well known to glassmakers.

The formation of corundum in an igneous rock as the consequence of the solution of argillaceous material is well illustrated by the case described by Prof. Busz. The mineral occurs round inclusions of clay slate in a felsite from South Brent. Many cases of the presence of corundum in igneous rocks under conditions which prove that it must have crystallised out of the magma, are now well known; and amongst the most interesting are those recently found in Hastings County, Canada, where the mineral occurs in dykes of syenite. In these, however, there appears to be no evidence that the excess of alumina is due to the solution of argillaceous rocks.

The remarkable synthetic experiments of Dr. Morosewicz give a complete and satisfactory account of the chemical and physical conditions under which corundum, spinelle, sillimanite and cordierite separate out of alumo-silicate magmas; and, therefore, of many of the natural occurrences above referred to. Alumina is soluble in magmas agreeing in composition with albite, nepheline and anorthite, or with mixtures of these, and crystallises out as corundum on prolonged cooling at high temperatures. If both silica and alumina are present in excess of that necessary to form felspar, sillimanite is formed until the excess of silica is used up, and then the remaining excess of alumina crystallises out as corundum. The presence of magnesia determines the formation of spinelle, or of cordierite, or of both, according to the excess of alumina and silica above that necessary to form felspar with the soda, potash and lime present. All these phenomena may be verified within the range of temperature in a Siemens' furnace, such as that used in glass-works. The minerals obtained are in every way similar, except as regards size, to those which occur in nature.

It thus appears that the "faithful companions" may be formed either by the metamorphism of sedimentary deposits, or 